\title{
PENGARUH VARIASI KONSENTRASI LOGAM MANGAN (Mn) TERHADAP EFISIENSI PENYISIHAN LOGAM BESI (Fe) PADA ADSORPSI MENGGUNAKAN SERBUK KULIT JAGUNG SEBAGAI ADSORBEN
}

\author{
Shinta Indah, Denny Helard, Rika Yedriana \\ Jurusan Teknik Lingkungan, Fakultas Teknik, Universitas Andalas \\ E-mail: shintaindah@ft.unand.ac.id
}

\begin{abstract}
ABSTRAK
Penelitian ini bertujuan untuk menganalisis pengaruh konsentrasi logam Mn dalam air terhadap efisiensi penyisihan logam Fe pada proses adsorpsi menggunakan adsorben kulit jagung. Penelitian dilakukan dengan sistem batch pada temperatur kamar dan kondisi optimum adsorpsi Fe yaitu pH adsorbat 4, diameter adsorben 0,075-0,250 mm dan dosis adsorben $20 \mathrm{~g} / \mathrm{L}$ dengan waktu pengamatan sampai 60 menit dan kecepatan pengadukan 100 rpm. Larutan yang digunakan berupa larutan artifisial dengan variasi konsentrasi $\mathrm{Fe}>\mathrm{Mn}$, $\mathrm{Fe}=\mathrm{Mn}$, dan $\mathrm{Fe}<\mathrm{Mn}$. Dari hasil penelitian didapatkan efisiensi penyisihan $\mathrm{Fe}$ pada variasi konsentrasi $\mathrm{Fe}>\mathrm{Mn}$, $\mathrm{Fe}=\mathrm{Mn}$, dan $\mathrm{Fe}<\mathrm{Mn}$ berturut-turut adalah 98,55\%; 95,64\%; 94,19\% dan penyisihan Mn sebesar 80,29\%; 87,30\%; 89,71\%. Hasil ini menunjukkan bahwa terjadi kompetisi adsorpsi antara Fe dan Mn pada adsorben kulit jagung, sehingga mempengaruhi proses difusi ion-ion logam tersebut untuk mencapai sisi aktif dari adsorben. Efisiensi penyisihan Fe semakin menurun dengan semakin meningkatnya konsentrasi Mn dalam larutann, namun efisiensi penyisihan Fe tetap lebih tinggi dari Mn pada semua variasi konsentrasi. $\mathrm{Hal}$ ini disebabkan selain karena proses adsorpsi dilakukan pada kondisi optimum penyisihan $\mathrm{Fe}$ dengan adsorben kulit jagung, juga karena jari-jari ion Fe yang lebih kecil dari Mn sehingga ion Fe cenderung lebih cepat teradsorpsi pada sisi aktif adsorben.
\end{abstract}

Kata kunci: adsorpsi, Fe, kompetisi, Mn, kulit jagung

\section{ABSTRACT}

This research aims to analyze the effect of Mn concentration on the removal efficiency of Fe from aqueous solution by maize husk as adsorbent. Batch experiments were carried out at ambient temperature with the optimum condition for Fe removal i.e. 4 of $\mathrm{pH}$ solution, 0,075-0,250 mm of adsorbent diameter and $20 \mathrm{~g} / \mathrm{L}$ of adsorbent dose with 60 min of contact time and $100 \mathrm{rpm}$ of agitation speed. The variation of Mn concentration in the aqueous solutions were $\mathrm{Fe}>\mathrm{Mn}, \mathrm{Fe}=\mathrm{Mn}$, and $\mathrm{Fe}<\mathrm{Mn}$. The results showed that the removal efficiencies of $F e$ in those variation of concentration were 98,55\%; 95,64\%; 94,19\%, while the removal efficiencies of Mn were 80,29\%; 87,30\%; 89,71\%, respectively. The results indicated that the competitive adsorption of Fe and $\mathrm{Mn}$ occurred in maize husk as adsorbent and affected the diffusion properties of those metal ions for the adsorption sites on the adsorbent. The removal efficiency of Fe decreased as the Mn concentration increased in the solution. However, the removal efficiencies of Fe were still higher than $\mathrm{Mn}$ in all variations of concentration. This may due to the condition that used in the adsorption process was the optimum condition of $\mathrm{Fe}$ adsorption onto maize husk and also to the ionic radii of Fe that is smaller than Mn, thus Fe ions reached the adsorption site faster than Mn.

Keywords: adsorption, competition, Fe, Mn, maize husk 


\section{PENDAHULUAN}

Di antara logam-logam berat esensial dalam air tanah, kandungan besi (Fe) dan mangan (Mn) memiliki kadar yang relatif tinggi. Kadar Fe dapat mencapai 10-100 mg/L pada air tanah dalam dengan kadar oksigen yang rendah (Effendi, 2003), sedangkan kadar Mn dapat mencapai 2 mg/L (Kawamura, 1991).

Berdasarkan penelitian yang telah dilakukan pada beberapa lokasi di Kota Padang, didapatkan konsentrasi logam $\mathrm{Fe}$ dalam air tanah berada pada rentang 0,9-10,6 mg/L (Gustilisa, 2006). Pemerintah melalui PP RI/82/ 2001 untuk kualitas muku kelas I tentang pengelolaan kualitas air dan pengendalian pencemaran air dan Permenkes No. 492/Menkes/PER/IV/2010 tentang persyaratan kualitas air minum, menetapkan konsentrasi besi adalah $0,3 \mathrm{mg} / \mathrm{L}$. Sementara menurut Permenkes RI No.416/Menkes/PER/IX/1990 tentang Syarat-syarat dan Pengawasan Kualitas Air, kadar maksimum yang diperbolehkan untuk Fe pada air bersih adalah $1 \mathrm{mg} / \mathrm{L}$. Oleh karena itu diperlukan metoda pengolahan yang tepat dalam penurunan logam-logam terlarut tersebut agar memenuhi baku mutu yang telah ditetapkan.

Salah satu metoda yang dapat digunakan untuk menyisihkan logam berat dalam air tanah adalah metoda adsorpsi. Adsorpsi adalah proses dimana molekul pencemar terkonsentrasi pada permukaan adsorben. Proses adsorpsi ini melibatkan dua komponen utama yaitu adsorbat yang merupakan substansi yang akan disisihkan dari cairan dan adsorben yang merupakan padatan dimana di atasnya terjadi pengumpulan substansi yang disisihkan (Reynold dan Richards, 1996).

Hasil studi membuktikan bahwa materialmaterial yang mengandung selulosa dapat digunakan untuk mengolah limbah logam berat (Igwe et al., 2005). Kulit jagung merupakan limbah pertanian yang mengandung selulosa dan hemiselulosa pada strukturnya (Kurakake et al., 2001). Penelitian tentang kemampuan kulit jagung sebagai adsorben dalam menyisihkan logam Fe dari air telah dilakukan dan didapatkan kapasitas adsorpsi sebesar 0,499 mg Fe/g serbuk kulit jagung (Indah et. al., 2016).
Keberadaan ion lain dalam sistem adsorpsi dapat mempengaruhi atau bahkan mengganggu proses adsorpsi yang terjadi. Hal ini disebabkan karena sisi-sisi aktif dari adsorben juga dapat mengadsorpsi ion lain selain ion target. Barros et al (2003) menyatakan bahwa keberadaan ion lain yaitu $\mathrm{Na}^{+}, \mathrm{K}^{+}, \mathrm{Mg}^{2+}$, dan $\mathrm{Ca}^{2+}$ dalam air berkompetisi dengan $\mathrm{Cr}^{3+}$ sehingga berpengaruh terhadap adsorpsi $\mathrm{Cr}^{3+}$ tersebut pada zeolit. Penelitian lain juga mengungkapkan bahwa keberadaan $\mathrm{Fe}^{2+}$ mengganggu adsorpsi $\mathrm{Mn}^{2+}$ oleh pithacelobium dulce carbon (Emmanuel \& Rao, 2008). Sementara penyisihan arsenat oleh nanoscale iron-manganese binary oxide-loaded zeolite tidak terpengaruh dengan keberadaan natural organic matter dalam larutan (Kong et al., 2014). Selain itu, penelitian tentang kompetisi adsorpsi ion $\mathrm{Zn}^{2+}, \quad \mathrm{Cd}^{2+}$ dan $\mathrm{Pb}^{2+}$ dalam larutan menggunakan kulit dan tongkol jagung sebagai adsorben yang dilakukan Igwe et al. (2005) mendapatkan hasil bahwa efisiensi penyisihan masing-masing ion logam dipengaruhi oleh keberadaan ion logam yang lain.

Penelitian ini bertujuan untuk menganalisis pengaruh keberadaan Mn terhadap efisiensi penyisihan Fe pada adsorpsi menggunakan kulit jagung sebagai adsorben. Dari penelitian ini dapat dipelajari kompetisi yang terjadi pada kedua logam untuk terikat pada sisi-sisi aktif adsorben. Proses adsorpsi dilakukan dengan sistem batch pada variasi konsentrasi awal $\mathrm{Fe}$ dan $\mathrm{Mn}$. Konsentrasi kedua ion logam pada semua perlakuan diukur dengan menggunakan Spektrofotometer Serapan Atom (SSA).

\section{METODOLOGI}

\section{Persiapan adsorben}

Kulit jagung yang digunakan sebagai adsorben didapatkan dari limbah industri kecil yang menggunakan jagung sebagai bahan bakunya. Industri kecil ini berlokasi di Belakang Olo Padang. Perlakuan awal terhadap kulit jagung adalah kulit jagung dibersihkan, dicuci dengan air, dipotongpotong, dan dijemur di udara terbuka (Indah et al., 2016)). Sebelum digunakan sebagai adsorben, kulit jagung digrinder dan diayak hingga diameter $(0,075-0,250) \mathrm{mm})$. Selanjutnya serbuk kulit jagung dicuci 
dengan akuades dan dikeringanginkan pada temperatur kamar selama 1 hari.

\section{Pembuatan Larutan Artifisial}

Larutan artifisial $\mathrm{Fe}$ dibuat dengan melarutkan Besi Amonium Sulfat $\left(\mathrm{Fe}\left(\mathrm{NH}_{4}\right)_{2}\right.$ $\left.\left(\mathrm{SO}_{4}\right)_{2} \cdot 6 \mathrm{H}_{2} \mathrm{O}\right)$ dengan aquades. Sementara larutan artifisial $\mathrm{Mn}$ dibuat dari Mangan Sulfat $\left(\mathrm{MnSO}_{4} \cdot 4 \mathrm{H}_{2} \mathrm{O}\right)$. Larutan yang digunakan untuk percobaan merupakan larutan campuran antara larutan artifisial $\mathrm{Fe}$ volume $50 \mathrm{ml}$ dan larutan artifisial $\mathrm{Mn}$ volume $50 \mathrm{ml}$ dengan variasi konsentrasi $\mathrm{Fe}$ $>\mathrm{Mn}, \mathrm{Fe}=\mathrm{Mn}$ dan $\mathrm{Fe}<\mathrm{Mn}$.

\section{Percobaan Adsorpsi}

Percobaan adsorpsi dilakukan secara duplo dengan sistem batch pada kondisi optimum adsorpsi $\mathrm{Fe}$ yaitu $\mathrm{pH}$ adsorbat 4 , diameter adsorben $0,075-0,250 \mathrm{~mm}$ dan dosis adsorben $20 \mathrm{~g} / \mathrm{L}$ dengan waktu pengamatan sampai 60 menit dn kecepatan pengadukan $100 \mathrm{rpm}$. Variasi konsentrasi larutan dipilih dari rentang konsentrasi logam $\mathrm{Fe}$ dan $\mathrm{Mn}$ dalam air tanah kota Padang yaitu berturutturut (1-10) $\mathrm{mg} / \mathrm{L}$ dan $(0,1-2) \quad \mathrm{mg} / \mathrm{L}$ (Gustilisa, 2006), sehingga didapatkan variasi konsentrasi dimana $\mathrm{Fe}>\mathrm{Mn}, \mathrm{Fe}=\mathrm{Mn}$, dan $\mathrm{Fe}<\mathrm{Mn}$. Tabel 1 menampilkan variasi konsentrasi Fe dan Mn yang digunakan pada percobaan adsorpsi.

Selanjutnya dilakukan percobaan adsorpsi Fe menggunakan adsorben kulit jagung pada sampel air tanah dengan variasi konsentrasi alamiahnya untuk membandingkan dengan hasil yang didapatkan pada percobaan adsorpsi pada larutan artifisial. Metode analisis konsentrasi $\mathrm{Fe}$ dan $\mathrm{Mn}$ dilakukan dengan Spektrofotometer Serapan Atom (SSA) pada panjang gelombang 248,3 nm untuk logam Fe (SNI 06-6989.4.2004) dan 279,5 nm untuk logam Mn (SNI 06-698952004).

Tabel 1. Variasi Konsentrasi Fe dan Mn pada Percobaan Adsorpsi

\begin{tabular}{|c|c|c|c|}
\hline No & $\begin{array}{c}\text { Variasi } \\
\text { Konsentrasi }\end{array}$ & $\begin{array}{c}\text { Konsentrasi } \\
\text { Fe (mg/L) }\end{array}$ & $\begin{array}{l}\text { Konsentrasi } \\
\text { Mn (mg/L) }\end{array}$ \\
\hline 1. & $\mathrm{Fe}>\mathrm{Mn}$ & \multirow{3}{*}{1} & 0,1 \\
\hline 2. & $\mathrm{Fe}=\mathrm{Mn}$ & & 1 \\
\hline 3. & $\mathrm{Fe}<\mathrm{Mn}$ & & 2 \\
\hline
\end{tabular}

\section{HASIL DAN PEMBAHASAN}

Hasil percobaan adsorpsi $\mathrm{Fe}$ menggunakan adsorben kulit jagung pada variasi konsentrasi $\mathrm{Fe}>\mathrm{Mn}, \mathrm{Fe}=\mathrm{Mn}$, dan $\mathrm{Fe}<\mathrm{Mn}$ ditampilkan pada Gambar 1. Dari Gambar 1 dapat dilihat bahwa efisiensi penyisihan Fe berkisar antara 89,82-98,54\% dan secara umum efisiensi mengalami peningkatan bersamaan dengan bertambahnya waktu sampai pada kondisi kesetimbangan yaitu pada menit ke-15. Setelah melewati kondisi ini, efisiensi penyisihan $\mathrm{Fe}$ pada ketiga variasi konsentrasi cenderung tidak mengalami peningkatan yang berarti. Pada variasi konsentrasi $\mathrm{Fe}<\mathrm{Mn}, 15$ menit pertama efisiensi penyisihan logam Mn yaitu 89,83\% kemudian meningkat pada menit ke 45 menjadi $92,73 \%$ dan naik menjadi $94,19 \%$ pada menit ke-60. Hal yang sama juga terjadi pada variasi konsentrasi $\mathrm{Mn}=\mathrm{Fe}$ dan $\mathrm{Fe}>\mathrm{Mn}$ dengan nilai efisiensi yang berbeda.

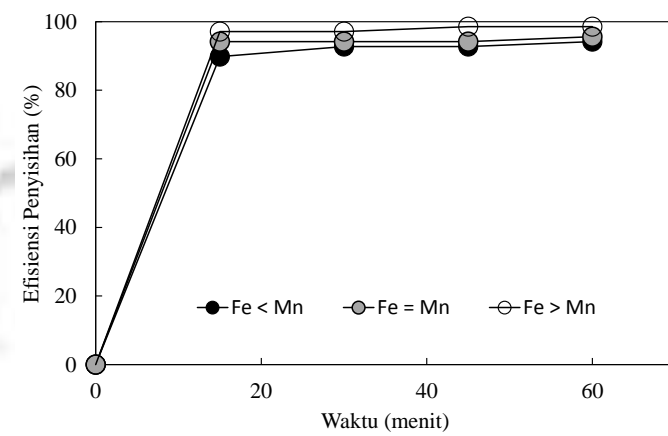

Gambar 1. Efisiensi penyisihan Fe pada proses adsorpsi menggunakan kulit jagung sebagai adsorben pada variasi konsentrasi Fe dan Mn.

Menurut Ju dan Ezuma (2014) pada awal waktu kontak tingkat adsorpsi ion lebih tinggi karena semua situs di adsorben kosong dan konsentrasi ion tinggi, tetapi akan terjadi penurunan jumlah situs adsorpsi yang tersedia, sehingga mengurangi tingkat adsorpsi karena telah mencapai kondisi kesetimbangan. Jumlah ion teradsorpsi pada saat kesetimbangan mencerminkan kapasitas adsorpsi maksimum dari adsorben. Selain itu, Mengistie et al. (2008) menyatakan efisiensi penyisihan meningkat dengan sangat cepat pada saat awal waktu kontak kemudian berlangsung konstan hingga mencapai waktu kesetimbangan dan setelah mencapai waktu kesetimbangan peningkatan 
efisiensi penyisihan berlangsung sangat lambat hingga mencapai titik jenuh.

Hasil proses adsorpsi juga menunjukan bahwa dari perbandingan efisiensi penyisihan $\mathrm{Fe}$ pada ketiga variasi konsentrasi ini, efisiensi penyisihan $\mathrm{Fe}$ paling tinggi diperoleh pada variasi konsentrasi $\mathrm{Fe}>\mathrm{Mn}$. Kemudian diikuti dengan efisiensi penyisihan variasi konsentrasi $\mathrm{Fe}=\mathrm{Mn}$, dan paling rendah pada variasi konsentrasi $\mathrm{Fe}<\mathrm{Mn}$. Hal ini mengungkapkan bahwa efisiensi penyisihan Fe menurun sejalan dengan meningkatnya konsentrasi Mn yang terdapat dalam larutan.

Lebih besarnya nilai efisiensi penyisihan logam $\mathrm{Fe}$ pada variasi konsentrasi $\mathrm{Fe}>\mathrm{Mn}$ dibandingkan variasi konsentrasi lainnya disebabkan oleh pengaruh variasi konsentrasi logam Mn yang diberikan pada larutan logam Fe yang memiliki konsentrasi tetap. Dalam hal ini logam $\mathrm{Fe}$ lebih banyak terserap di saat keberadaan atau konsentrasi logam Mn tersebut lebih rendah.

Di samping itu pada saat variasi konsentrasi $\mathrm{Fe}>\mathrm{Mn}$, memberikan keleluasaan bagi $\mathrm{Fe}$ untuk menguasai proses transfer massa sehingga memperbesar kesempatan Fe untuk berkontak atau bertumbukan dengan sisi aktif adsorben. Hal yang sama juga terjadi pada penelitian Baral (2006) yang menyatakan bahwa dengan semakin besarnya jumlah ion $\mathrm{Cr}(\mathrm{VI})$ suatu larutan dalam proses adsorpsi menyebabkan semakin besarnya keleluasaan bagi logam $\mathrm{Cr}(\mathrm{VI})$ tersebut untuk menguasai proses transfer massa dari adsorbat ke adsorben.

Dalam mempelajari pengaruh variasi konsentrasi Mn terhadap efisiensi penyisihan Fe ini, juga perlu dilihat besarnya efisiensi penyisihan Mn. Dari hasil analisa, didapatkan bahwa efisiensi penyisihan $\mathrm{Mn}$ berkisar antara 73,73-89,71\%, lebih rendah dari efisiensi penyisihan $\mathrm{Fe}$ yaitu 89,8298,54\%. Efisiensi penyisihan Mn tertinggi diperoleh pada variasi konsentrasi $\mathrm{Fe}<\mathrm{Mn}$ yaitu $89,71 \%$, diikuti efisiensi penyisihan pada variasi konsentrasi $\mathrm{Fe}=\mathrm{Mn}$ dan $\mathrm{Fe}>\mathrm{Mn}$ yaitu berturut-turut $87,30 \%$ dan $80,30 \%$. Efisiensi penyisihan Mn semakin rendah jika konsentrasi $\mathrm{Fe}$ yang terdapat dalam larutan semakin tinggi. Hasil lengkap penyisihan Mn dapat dilihat pada Gambar 2.

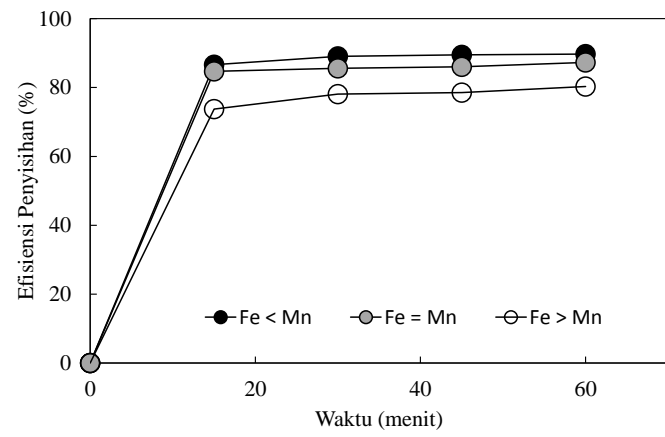

Gambar 2. Efisiensi penyisihan Mn pada proses adsorpsi menggunakan kulit jagung sebagai adsorben pada variasi konsentrasi $\mathrm{Fe}$ dan Mn.

Gambar 2 menunjukan bahwa semakin rendah variasi konsentrasi Mn yang diberikan pada konsentrasi Fe yang tetap, menyebabkan adsorpsi Mn pada kulit jagung menjadi menurun. Hal ini membuktikan bahwa faktor konsentrasi memegang peranan penting dalam proses adsorpsi, dimana semakin tinggi konsentrasi adsorbat, semakin banyak ionnya terdapat dalam larutan, semakin tinggi pula kemungkinannya untuk dapat teradsorpsi, sehingga akan diperoleh efisiensi penyisihan yang lebih tinggi pula (Eckenfelder, 2000). Selain itu, lebih rendahnya efisiensi penyisihan $\mathrm{Mn}$ dibanding $\mathrm{Fe}$ juga disebabkan karena kondisi percobaan yang digunakan adalah kondisi optimum untuk penyisihan $\mathrm{Fe}$, sehingga kemampuan $\mathrm{Mn}$ dalam bersaing dengan logam $\mathrm{Fe}$ untuk terikat pada sisi aktif dari adsorben menjadi tidak optimum.

Untuk lebih jelasnya, perbedaan efisiensi penyisihan antara Fe dan Mn dari masingmasing variasi konsentrasi dapat dilihat pada Gambar 3, 4 dan 5. Pada Gambar 3, dengan variasi konsentrasi awal $\mathrm{Fe} 1 \mathrm{mg} / \mathrm{L}$ dan $\mathrm{Mn}$ 0,1 mg/L dalam 60 menit proses adsorpsi, terlihat bahwa perbedaan efisiensi penyisihan $\mathrm{Fe}$ dan $\mathrm{Mn}$ relatif besar dimana didapatkan efisiensi penyisihan $\mathrm{Fe}$ berada kisaran nilai 97,09-98,54\% dan efisiensi penyisihan Mn dengan kisaran 73,73$80,30 \%$.

Pada variasi konsentrasi $\mathrm{Fe}=\mathrm{Mn}$ yaitu 1 $\mathrm{mg} / \mathrm{L}$, diperoleh efisiensi penyisihan $\mathrm{Fe}$ dan Mn berturut-turut berkisar antara 94,19$95,64 \%$ dan $84,68-87,30 \%$. Hasil ini menunjukan bahwa perbedaan tingkat efisiensi masih terjadi dan efisiensi 
penyisihan $\mathrm{Fe}$ tetap memiliki nilai yang lebih tinggi dari pada efisiensi penyisihan Mn. Hal tersebut dapat dilihat lebih jelas pada Gambar 4.

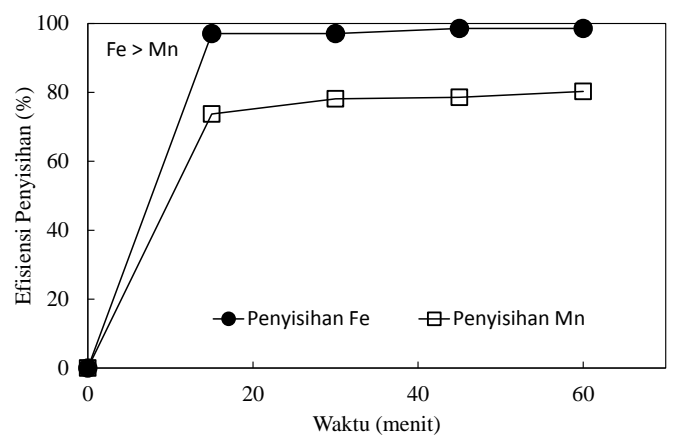

Gambar 3. Perbandingan efisiensi penyisihan Fe dan Mn pada variasi konsentrasi $\mathrm{Fe}>\mathrm{Mn}$ (konsentrasi awal $\mathrm{Fe}=1 \mathrm{mg} / \mathrm{L}$; konsentrasi awal $\mathrm{Mn}=0,1 \mathrm{mg} / \mathrm{L})$.

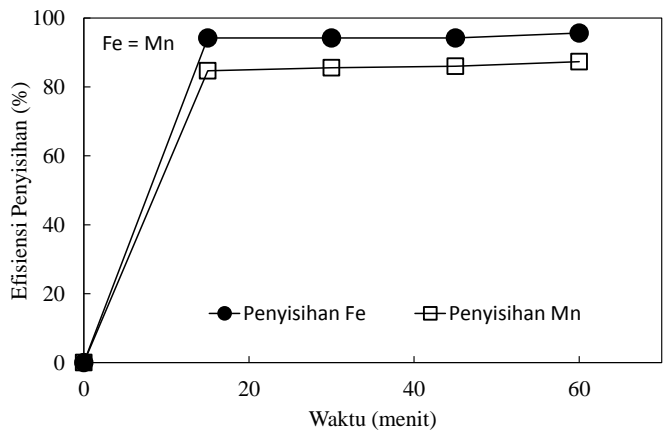

Gambar 4. Perbandingan efisiensi penyisihan $\mathrm{Fe}$ dan $\mathrm{Mn}$ pada variasi konsentrasi $\mathrm{Fe}=\mathrm{Mn}$ (konsentrasi awal $\mathrm{Fe}=1 \mathrm{mg} / \mathrm{L}$; konsentrasi awal $\mathrm{Mn}=1 \mathrm{mg} / \mathrm{L})$.

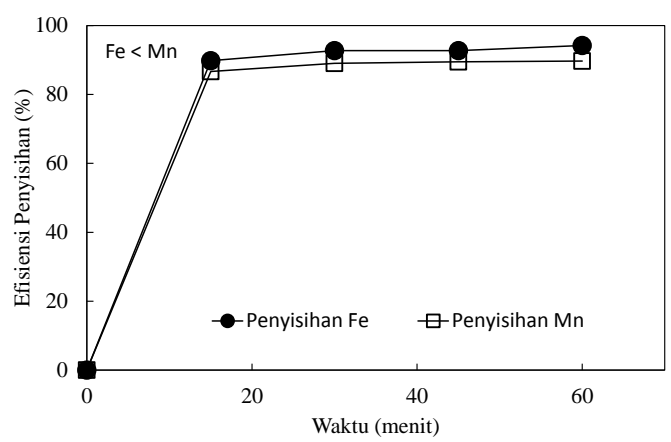

Gambar 5. Perbandingan efisiensi penyisihan Fe dan Mn pada variasi konsentrasi $\mathrm{Fe}<\mathrm{Mn}$ (konsentrasi awal $\mathrm{Fe}=1 \mathrm{mg} / \mathrm{L}$; konsentrasi awal $\mathrm{Mn}=2 \mathrm{mg} / \mathrm{L})$.

Sementara pada Gambar 5 ditampilkan perbandingan efisiensi penyisihan $\mathrm{Fe}$ dan $\mathrm{Mn}$ pada variasi konsentrasi $\mathrm{Fe}<\mathrm{Mn}$, dimana konsentrasi $\mathrm{Fe}$ adalah $1 \mathrm{mg} / \mathrm{L}$ dan $\mathrm{Mn} 2$ $\mathrm{mg} / \mathrm{L}$. Pada kondisi ini, didapatkan efisiensi penyisihan Fe dan Mn berturut-turut berada dalam rentang $89,83-94,19 \%$ dan 86,65 $89,71 \%$. Hal ini menunjukan bahwa walaupun konsentrasi awal Mn dalam larutan lebih tinggi dari $\mathrm{Fe}$, namun efisiensi penyisihan $\mathrm{Fe}$ pada proses adsorpsi menggunakan adsorben kulit jagung tetap lebih tinggi daripada efisiensi penyisihan $\mathrm{Mn}$.

Dari ketiga gambar yang menampilkan perbandingan efisiensi penyisihan $\mathrm{Fe}$ dan Mn, dapat dibuktikan bahwa terjadi kompetisi adsorpsi antara $\mathrm{Fe}$ dan $\mathrm{Mn}$ pada adsorben kulit jagung. Kompetisi adsorpsi ini mempengaruhi proses difusi ion-ion logam tersebut untuk mencapai sisi aktif dari adsorben, sehingga dapat mengakibatkan penurunan efisiensi penyisihan logam-logam tersebut (Igwe et al., 2005).

Selain itu, juga dapat dilihat bahwa efisiensi penyisihan logam Fe selalu memiliki kisaran nilai yang lebih tinggi dari logam $\mathrm{Mn}$. Terlihat juga efisiensi penyisihan logam $\mathrm{Fe}$ memiliki nilai tertinggi jika konsentrasinya lebih besar dari konsentrasi logam Mn. Hal ini terjadi karena selain didukung oleh kondisi optimum penyisihan untuk logam $\mathrm{Fe}$, juga disebabkan karena adanya kecendrungan bahwa $\mathrm{Fe}$ lebih mudah disisihkan daripada Mn. Hal ini dimungkinkan karena sifat kimia seperti jarijari ion (Igwe et al., 2005) yang dimiliki oleh Fe dan Mn. Jari-jari ion adalah jari-jari dari kation atau anion yang dihitung berdasarkan jarak antara dua inti kation dan anion dalam kristal ionik. Dalam satu golongan pada sistem periodik unsur, dari atas ke bawah, jari-jari ion cenderung semakin besar, sebagaimana pertambahan kulit elektron. Dalam periode, dari kiri ke kanan, terjadi pengecilan jari-jari ion (Syukri, 1999). Dari tabel periodik dapat dilihat bahwa $\mathrm{Fe}$ dan $\mathrm{Mn}$ berada dalam periode yang sama dengan urutan nomor atom $\mathrm{Fe}=26$ dan $\mathrm{Mn}=25$, sehingga posisi $\mathrm{Fe}$ berada lebih ke kanan dari Mn. Dari posisi tersebut, dapat disimpulkan bahwa jari-jari ion $\mathrm{Fe}$ lebih kecil dari Mn. Dari tabel periodik diketahui lebih lanjut bahwa jarijari ion $\mathrm{Fe}$ dan $\mathrm{Mn}$ adalah berturut-turut 0,75 $\AA$ dan 0,81 A. Semakin kecil jari-jari ion suatu logam, daya tarik inti dari ion tersebut juga akan semakin besar, yang mengakibatkan logam tersebut semakin cepat berikatan dengan sisi aktif adsorben 
(Syukri, 1999; Igwe et al., 2005). Dalam hal ini, karena jari-jari ion $\mathrm{Fe}$ lebih kecil dari Mn, ion Fe lebih cepat teradsorpsi ke sisi aktif adsorbent kulit jagung dibandingkan dengan Mn.

\section{Percobaan Aplikasi dengan Menggunakan Sampel Air Tanah}

Untuk membuktikan kemampuan serbuk kulit jagung sebagai adsorben untuk penyisihan logam $\mathrm{Fe}$ dan $\mathrm{Mn}$, dilakukan aplikasi proses adsorpsi tersebut untuk menyisihkan logam $\mathrm{Fe}$ dan $\mathrm{Mn}$ yang terkandung dalam air tanah. Sampel air tanah diambil dari sumur yang berlokasi di Kampus Fakultas Teknik, Universitas Andalas. Dari hasil analisis konsentrasi dengan SSA didapatkan kandungan $\mathrm{Fe}$ yang lebih tinggi dari Mn dalam sampel air tanah yaitu berturut-turut adalah $6,02 \mathrm{mg} / \mathrm{L}$ dan $0,79 \mathrm{mg} / \mathrm{L}$. Setelah dilakukan adosrpsi pada keadaan optimum yaitu $\mathrm{pH}$ adsorbat 4, diameter adsorben $0,075-0,250 \mathrm{~mm}$ dan dosis adsorben $20 \mathrm{~g} / \mathrm{L}$ dengan waktu pengamatan sampai 60 menit dan kecepatan pengadukan $100 \mathrm{rpm}$, diperoleh hasil seperti disajikan pada Gambar 6.

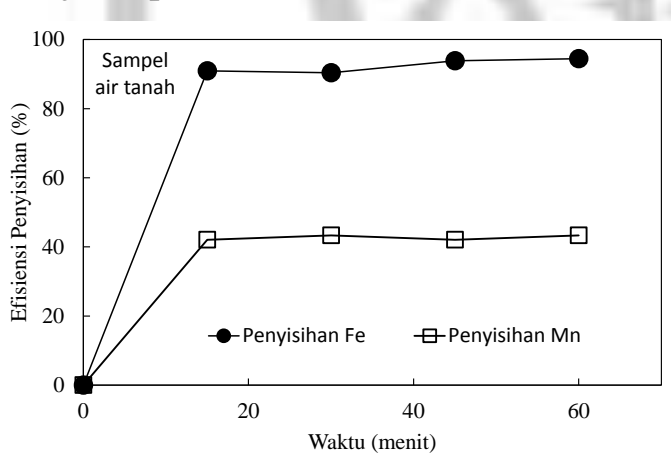

Gambar 6. Perbandingan efisiensi penyisihan Fe dan Mn dari sampel air tanah dengan menggunakan kulit jagung sebagai adsorben (konsentrasi awal $\mathrm{Fe}=6,02 \mathrm{mg} / \mathrm{L}$; konsentrasi awal $\mathrm{Mn}=0.79 \mathrm{mg} / \mathrm{L}$ )

Gambar 6 menunjukan bahwa dengan kondisi konsentrasi awal Fe yang lebih besar dari Mn, didapatkan efisiensi penyisihan $\mathrm{Fe}$ yang lebih tinggi juga dari Mn. Dalam waktu pengamatan selama 60 menit, efisiensi penyisihan $\mathrm{Fe}$ berada dalam rentang 90,9694,46\% dan Mn berkisar 42,04-43,31\%. Efisiensi penyisihan yang didapat lebih rendah dari efisiensi yang diperoleh pada percobaan dengan larutan artifisial dan rentang perbedaan efisiensi penyisihan $\mathrm{Fe}$ dan Mn juga lebih besar. Hal ini disebabkan karena dalam sampel air tanah juga terkandung beragam ion lain yang juga berkompetisi untuk dapat teradsorpsi pada sisi aktif adosriben kulit jagung, sehingga menggangu efisiensi penyisihan Fe dan Mn.

\section{SIMPULAN}

Terjadi kompetisi adsorpsi Fe dan Mn pada proses adsorpsi menggunakan adsorben kulit jagung;

Pada variasi konsentrasi logam Mn dalam larutan logam $\mathrm{Fe}$ yang tetap yaitu $\mathrm{Fe}>\mathrm{Mn}$; $\mathrm{Fe}=\mathrm{Mn}$; dan $\mathrm{Fe}<\mathrm{Mn}$, diperoleh efisiensi penyisihan logam $\mathrm{Fe}$ berturut-turut adalah 98,55\%; 95,64\%; 94,19\% dan penyisihan Mn adalah 80,29\%; 87,30\%; 89,71\%.

Keberadaan logam Mn dalam larutan mempengaruhi efisiensi penyisihan $\mathrm{Fe}$ oleh adsorben kulit jagung, dimana didapatkan bahwa semakin tinggi konsentrasi Mn, maka efisiensi penyisihan $\mathrm{Fe}$ semakin menurun;

Efisiensi penyisihan masing-masing logam menjadi tidak optimal jika konsentrasi salah satu logam mendominasi atau lebih besar dari logam lainnya;

Efisiensi penyisihan terhadap logam $\mathrm{Fe}$ selalu lebih besar daripada Mn di setiap variasi konsentrasi yang diuji disebabkan karena proses adsorpsi dilakukan pada kondisi optimum penyisihan $\mathrm{Fe}$ pada adsorben kulit jagung dan lebih kecilnya jari-jari ion logam Fe daripada jari-jari ion logam $\mathrm{Mn}$, sehingga ion $\mathrm{Fe}$ lebih cepat teradsorpsi ke sisi aktif adsorbent kulit jagung dibandingkan dengan $\mathrm{Mn}$.

\section{UCAPAN TERIMAKASIH}

Penulis mengucapkan terima kasih atas bantuan dana untuk penelitian ini kepada DIPA Universitas Andalas, sesuai dengan Surat Perjanjian Pelaksanaan Pekerjaan Penelitian Nomor: 088/H.16/PL/DIPA/I/2009, tanggal 2 April 2009.

\section{DAFTAR PUSTAKA}

Barros, M.A.S.D., Zola, A.S., Arroyo, P.A., Sousa-Aguiar, E.F., Tavares, C.R.G. (2003) Binary Ion Exchange of Metal Ions in $Y$ and $X$ Zeolites. Brazilian 
Journal of Chemical Engineering. Vol. 20, No. 04, pp. $413-421$.

Eckenfelder. (2000). Industrial Water Pollution Control. Mc Graw-Hill. Singapura.

Effendi, Hefni. 2003. Telaah Kualitas Air. Kanisius, Yogyakarta.

Emmanuela, K.A. dan Rao, V.A. (2008) Adsorption of Mn (II) from Aqueous Solutions using Pithacelobium Dulce Carbon. Rasayan Journal of Chemistry. Vol.1, No.4, pp 840-852.

Gustilisa, R. 2006. Penyisihan Logam Fe dengan Menggunakan Expanded Perlite Sungai Geringging Pariaman Sebagai Adsorben. Tugas Akhir. Tugas Akhir. Teknik Lingkungan Fakultas Teknik Universitas Andalas. Padang.

Igwe, J.C., Ogunewe, D.N., Abia, A.A. 2005. Competitive Adsorption of Zn(II), $\mathrm{Cd}(\mathrm{II})$ and $\mathrm{Pb}$ (II) Ions from Aqueous and Non-Aqueous Solution by Maize Cob and Husk. African Journal of Biotechnology. Vol. 4, No. 10, (10), pp. 1113-1116.

Indah, S., Helard, D., Sasmita, A. (2016). Utilization of Maize Husk (Zea mays L.) as Low-cost Adsorbent in Removal of Iron from Aqueous Solution. Water Science \& Technology. Vol 73, No.12, pp 2929-2935.
Ju, O., and Ezuma, I. (2014). Adsorption Studies of Heavy Metals by Low-Cost Adsorbents. Journal of Applied Sciences and Environmental Management, Vol. 18, No. 3, pp 443-448.

Kawamura, S. 1991. Integrated Design of Water Treatment Facilities. John Willey $\&$ Sons Inc. New York.

Kurakake, M., Kisaka, W., Ouchi, K., Komaki, T. (2001). Pretreatment with Ammonia Water for Enzymatic Hydrolysis of Corn Husk, Bagasse, and Switchgrass. Applied Biochemistry and Biotechnology. Vol. 90, Issue 3, pp 251259.

Kong, S., Wang Y., Zhan, H., Liu, M., Liang, L., Hu, Q. (2014). Competitive adsorption of humic acid and arsenate on nanoscale iron-manganese binary oxideloaded zeolite in groundwater. Journal of Geochemical Exploration. Vol. 144, pp 220-225.

Mengistie, A A., Rao, S., Rao P., and Singanan, M. (2008). Removal of Lead (II) from Aquoeus Solution Using Activated Carbon from Mitilia Ferruginea Plant Leaves. Bulletin of the Chemical Society of Ethiopia, Vol. 22, No. 3, pp. 349-360

Reynold, T.D. dan Richard, P.A. (1996). Unit Operation and Processes in Environmental Engineering. PWS Publishing Company. California. 